\title{
Association between Biogas Quality and Digester Temperature for Selected Animal Dung-Aided Water Hyacinth Digestion Mixes
}

\author{
${ }^{1 *} \mathrm{OJO}, \mathrm{OM} ;{ }^{1}$ BABATOLA, JO \\ Department of Civil Engineering, Federal University of Technology, Akure, P.M.B 704, Ondo State, Nigeria \\ *Corresponding Author Email: omojo@futa.edu.ng
}

\begin{abstract}
In this study, the association between biogas qulaity and digester temperature for selected animal dung-aided water hyacinth digestion mixes was evaluated. Substrates utilized in this study are water hyacinth (WH), poultry manure (PM) and cow dung (CD) and pig dung (PD). Thirty-one (31) co-digestion mix ratios were used in this study. The temperature ranged from 28.6 to $32.20 \mathrm{C}$ for the PD-aided $\mathrm{WH}$ digestion, 28.2 to $31.40 \mathrm{C}$ for the CD-aided WH digestion and 28.2 to $31.80 \mathrm{C}$ for the PM-aided WH digestion. This shows that the digestion process occurred within the mesophilic temperature range. The data obtained were analyzed using non-linear parameter estimation. The results revealed that the PM-aided WH mix produced more gas but with less methane content compared to the CDaided and PD-aided WH digestion mix. The results further revealed that the best quality of gas produced by the PD-aided WH digestion. The association between the temperature and gas quality was positive suggesting that an increase in temperature within the digestion leads to an increase in the quality of gas produced.
\end{abstract}

\section{DOI: $\underline{\text { https://dx.doi.org/10.4314/jasem.v24i6.2 }}$}

Copyright: Copyright $(\mathrm{C} 2020$ Ojo and Babatola. This is an open access article distributed under the Creative Commons Attribution License (CCL), which permits unrestricted use, distribution, and reproduction in any medium, provided the original work is properly cited.

Dates: Received: 03 April 2020; Revised: 20 May 2020; Accepted: 01 June 2020

Keywords: Biogas quality, temperature, co-digestion, animal dung, water hyacinth

Temperature is a key process parameter that influences the design of anaerobic digesters as well as gas production rate during anaerobic digestion. Depending on prevailing conditions, methane can be produced within a fairly wide range of temperature. Biogas can be produced in temperature conditions that are psychrophilic $\left(-10^{\circ} \mathrm{C}\right.$ to $\left.30^{\circ} \mathrm{C}\right)$, mesophilic $\left(20^{\circ} \mathrm{C}\right.$ to $\left.50^{\circ} \mathrm{C}\right)$ and thermophilic $\left(50^{\circ} \mathrm{C}\right.$ to $\left.75^{\circ} \mathrm{C}\right)$ (Parker et al., 2002; Shuler and Kargi, 2002; Deublein and Steinhauser, 2008). Ojo et al. (2018) carried out a multiple regression analysis to examine the determinants of cumulative volume of gas produced from different co-digested mixes of PD and WH. From that study, the temperature ranged from 28.6 to 32.2 ${ }^{\circ} \mathrm{C}$ for the PD - aided WH digestion. This shows that the digestion process occurred within the mesophilic temperature range, which, according to Wang et al. (2009), is ideal for Anaerobic Digestion. Mesophilic and thermophilic conditions present different reactor design and operational advantages and drawbacks. During thermophilic digestion both greater destruction of pathogens and higher substrate degradation can be achieved, but the microbe population is more sensitive to environmental conditions such as temperature fluctuations, changes in organic loading and $\mathrm{pH}$ (Angelidaki et al., 2007; Chen et al., 2008; Gerardi, 2003; Poliafico, 2007). In addition, thermophilic conditions require a large amount of heat energy that reduces the net energy production (El-Mashad et al., 2004). According to Parker et al. (2002), Ward (2008) and Angelidaki et al. (2007), most anaerobic digesters are designed to operate in either the mesophilic or thermophilic temperature respectively range (with optima at 35 and $55^{\circ} \mathrm{C}$ ) to maximize biogas yield. The importance of system stability, hydraulic retention time of the substrate, solids retention time and pathogenic bacteria destruction will determine if a mesophilic or thermophilic process temperature is targeted. Knottier (2003) reported that the process of anaerobic digestion runs at its optimum temperature range of 25 to $38^{\circ} \mathrm{C}$ (mesophilic conditions), where temperatures near to $38^{\circ} \mathrm{C}$ have resulted in greater stability of the digestion process. Likewise, a mesophilic treatment at $38^{\circ} \mathrm{C}$ reportedly destroys $99.9 \%$ of pathogens (Erickson et al., 2004). The process $\mathrm{pH}$, operating pressure, and biogas quantity 
and quality are monitored, along with temperature, to maintain the stability of the system and to promote a healthy population of the methane producing bacteria. Abdel-Hadi and El-Azeem (2008) stated that biogas and methane production were positively correlated with temperature. In general, high temperature gives a higher methane production rate. Regardless of the operating temperature, the process of $\mathrm{AD}$ generates two main products. These products are digested organic material and biogas. The digested organic material, or effluent, is typically referred to as digestate and is comprised of solids that are applicable as a nutrient rich soil amendment material and liquor that has a high phosphorous and nitrogen value and can be applied as a nutrient rich liquid fertilizer. Parker et al. (2002) discovered that the volume of biogas produced in earthen reactors was reduced during winter months. Parker et al. (2002) recommended an operating temperature in the middle of the mesophilic temperature range for improved performance with a high solids anaerobic digester using cattle manure.

Parker et al. (2002) also recommended that heat be provided to the digester during cooler months to ensure the target temperature and biogas production performance was maintained. According to Rastogi et al. (2008) the ambient temperature has a great influence on the methanogenic community in biogas reactors, although constant temperature is of high priority in any biogas fermenter. Most of the methanogenic microorganisms belong to the mesophilics. Only a few are thermophilic. Methanogenics are sensitive to rapid changes of temperature. Thermophilic methanogens are more temperature-sensitive than mesophilics. In general, the energy balance is better in the mesophilic range than in the thermophilic range (Deublein and Steinhauster, 2008). In this study, the association between biogas qulaity and digester temperature for selected animal dung-aided water hyacinth digestion mixes was evaluated.

\section{MATERIALS AND METHODS}

Sample collection: The substrates utilized in this study are water hyacinth $(\mathrm{WH})$, poultry manure (PM), cow dung (CD) and pig dung (PD). WH was harvested from a private pond in Akure, Ondo State while PM, $\mathrm{CD}$ and PD were collected from the animal farm of the Federal University of Technology, Akure. Thirty-one (31) co-digestion mix ratios were used in this study. The mix ratios were selected using fractional factorial analysis.

Sample preparation: Fresh water hyacinth (leaves, stem and root) on collection were chopped to small sizes of about $2 \mathrm{~cm}$ as shown in Plate 1.

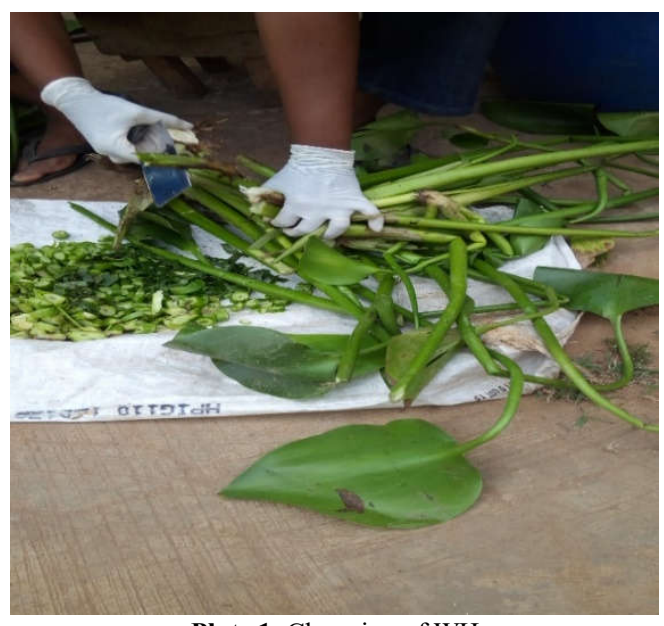

Plate 1: Chopping of WH

The feedstocks were appropriately weighed. Plate 2 shows the weighing of cow dung. As suggested by Tchobanoglous et al. (2003) and Fekadu (2014), the substrates were mixed with appropriate amount of water in order to achieve the recommended $8 \%$ of total solids content in the fermentation slurry. The quantity of water added was determined using equation 1.

$$
\mathrm{Y}=\frac{\mathrm{mTS}-8 \% \mathrm{X}}{8 \%}
$$

Where, mTS is the mass of total solids, $\mathrm{X}$ is the mass of fresh substrate, $\mathrm{Y}$ is the mass of water added to get $8 \%$ total solids in the digester

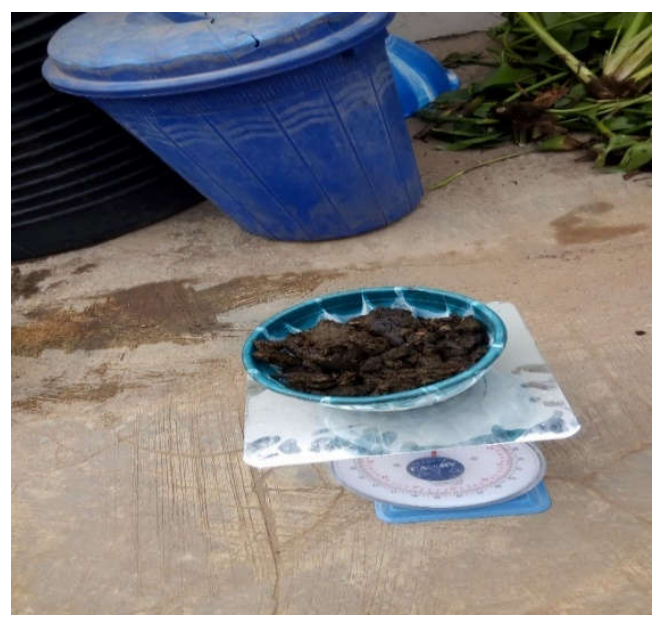

Plate 2: Weighing of dung

Sample analysis: 25 litre capacity plastic prototype digesters were used in this study (Ojo, 2017) and each experimental run was assessed over a period of 40 days. The digesters had a thickness of $2 \mathrm{~mm}$, height of $400 \mathrm{~mm}$ and width of $320 \mathrm{~mm}$. The total volume digester (VDC) was calculated shown in equation 2 : 


$$
\text { TVD }=25 \mathrm{~L}
$$

But the Volume of the Digestion Chamber (VDC) should be $\frac{3}{4}$ the TVD to allow for gas collection. Therefore, VDC was calculated using equations 3 and 4

$$
\begin{aligned}
& \mathrm{VDC}=\frac{3}{4} \times \mathrm{TVD} \\
& \mathrm{VDC}=\frac{3}{4} \times 25=18.75 \mathrm{~L}
\end{aligned}
$$

One-fourth of the TVD should be allowed for gas collection, hence, the Volume of the Gas Chamber (VG) was calculated using equations 5 and 6.

$$
\begin{gathered}
\mathrm{VG}=\frac{1}{4} \times \mathrm{TVD} \\
\mathrm{VG}=\frac{1}{4} \times 25=6.25 \mathrm{~L}
\end{gathered}
$$

The temperature within the digester was measured using a mercury thermometer calibrated in degree centigrade. The quality of the gas produced was determined using a locally fabricated potassium hydroxide $(\mathrm{KOH})$ solution biogas determination apparatus. The apparatus was designed according to procedures specified by Abdel-Hadi (2008). The apparatus was fabricated using locally available materials. The apparatus consists of a U-tube glass with an internal diameter of $13 \mathrm{~mm}$. The tube was filled with $\mathrm{KOH}$ solution to a height of $200 \mathrm{~mm}$ each on both legs. The U-tube was hitched with a tap to adjust the level of solution after removal of $\mathrm{CO}_{2}$. The tube was fitted with an inlet for receiving biogas from the digester and with a gas outlet to release the methane gas after the removal of $\mathrm{CO}_{2}$. The $\mathrm{CO}_{2}$ in the biogas was absorbed by the $\mathrm{KOH}$ solution leading to an increase in the volume of the solution. The increase in volume was taken as the volume of $\mathrm{CO}_{2}$ in the biogas sample. The apparatus is shown in Plate 3 . The percentage of $\mathrm{CO}_{2}$ was calculated using equation 7 .

$$
\% \text { volume of } \mathrm{CO}_{2}=\frac{V_{1}-V_{2}}{V_{1}} \times 100
$$

Where $V_{l}$ is the volume of biogas before removal of $\mathrm{CO}_{2}, \mathrm{ml} ; V_{2}$ is the volume of methane and the other gases after removal of $\mathrm{CO}_{2}, \mathrm{ml}$.

The percentage of $\mathrm{CH}_{4}$ was calculated using equation 8. $\%$ volume of $\mathrm{CH}_{4}=100-\left[\mathrm{CO} 2 \%+3 \%\left(\mathrm{H}_{2} \mathrm{~S}\right.\right.$ and
the other gases

Where $3 \%$ is the average of $\mathrm{H}_{2} \mathrm{~S}$ and the other gases percentage. The percentage volume of $\mathrm{H}_{2} \mathrm{~S}$ and other gases is $1-5 \%$ (GTZ-GATE, 1999)

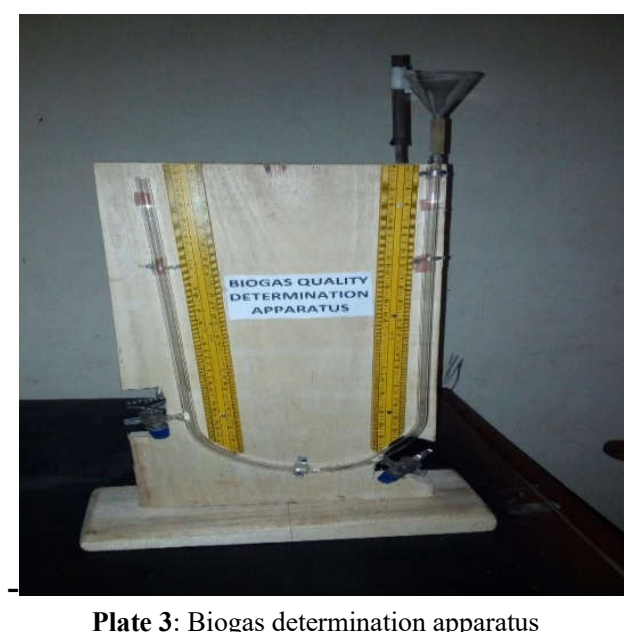

Data analysis: The results obtained from the experiments were analyzed using IBM SPSS Statistics 22. Analysis of variance (ANOVA) test was conducted to determine whether there is a significant difference between the biogas quality and temperature within the digester. A Post-Hoc test using Duncan multiple range test was conducted to identify the difference in the relationship that exist between the variables. A multiple regression analysis was carried out to examine the relationship between biogas quality and temperature for the mixes of the animal dung aided WH digestion.

\section{RESULTS AND DISCUSSIONS}

Association between biogas quality $\left(\% \mathrm{CH}_{4}\right)$ and Temperature: The temperature at which digestion occurs can significantly affect the biogas production in terms of the conversion, kinetics, stability and consequently the methane yield. The temperature ranged from 28.6 to $32.2{ }^{\circ} \mathrm{C}$ for the $\mathrm{PD}$-aided $\mathrm{WH}$ digestion, 28.2 to $31.4{ }^{\circ} \mathrm{C}$ for the $\mathrm{CD}$-aided $\mathrm{WH}$ digestion and 28.2 to $31.8{ }^{\circ} \mathrm{C}$ for the $\mathrm{PM}$-aided $\mathrm{WH}$ digestion. This shows that the digestion process occurred within the mesophilic temperature range, which is ideal for $\mathrm{AD}$ as this temperature range adequately supports microbial activities within the digester (Wang et al., 2009). The results obtained for the mixes revealed a strong association between the temperature within the digester and the quality of the gas produced. The correlation was statistically significant at $1 \%$ which means that the temperature within the digester clearly affects the quality of the gas produced with up to $99 \%$ confidence level. The association between the temperature and gas quality was positive (as shown in Figures 1, 2 and 3), implying that an increase in temperature within the digestion leads to an increase in the quality of gas produced. 


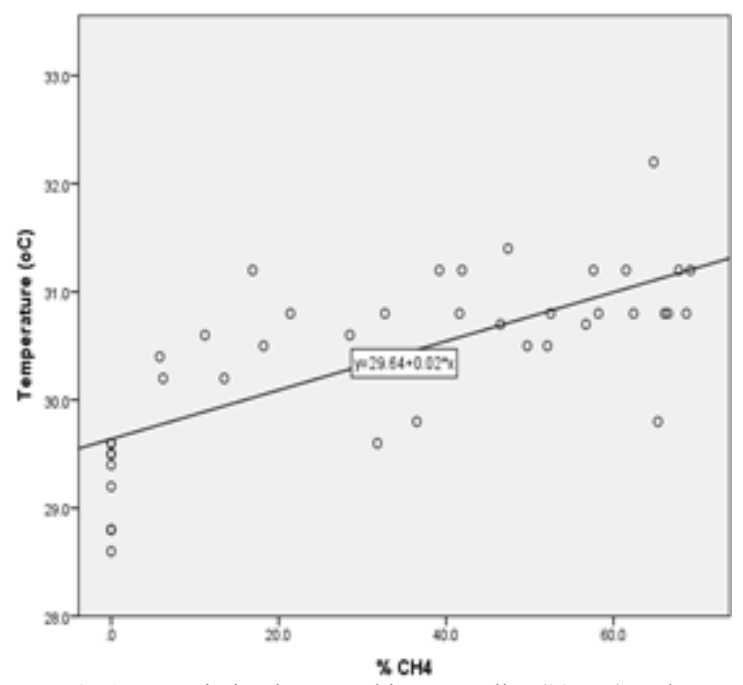

Fig 1: Association between biogas quality $\left(\% \mathrm{CH}_{4}\right)$ and Temperature for $\mathrm{PD}$-aided $\mathrm{WH}$ digestion

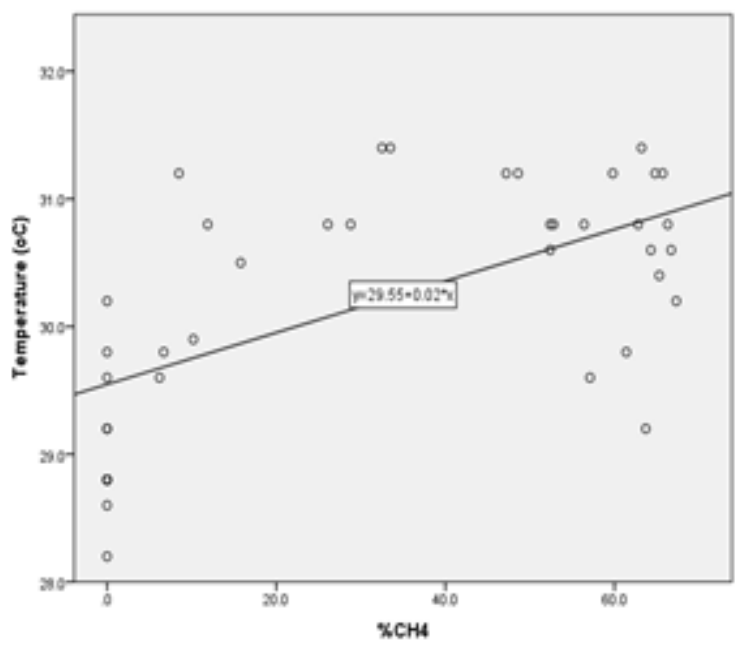

Fig 2: Association between biogas quality $\left(\% \mathrm{CH}_{4}\right)$ and Temperature for $\mathrm{CD}$-aided WH digestion

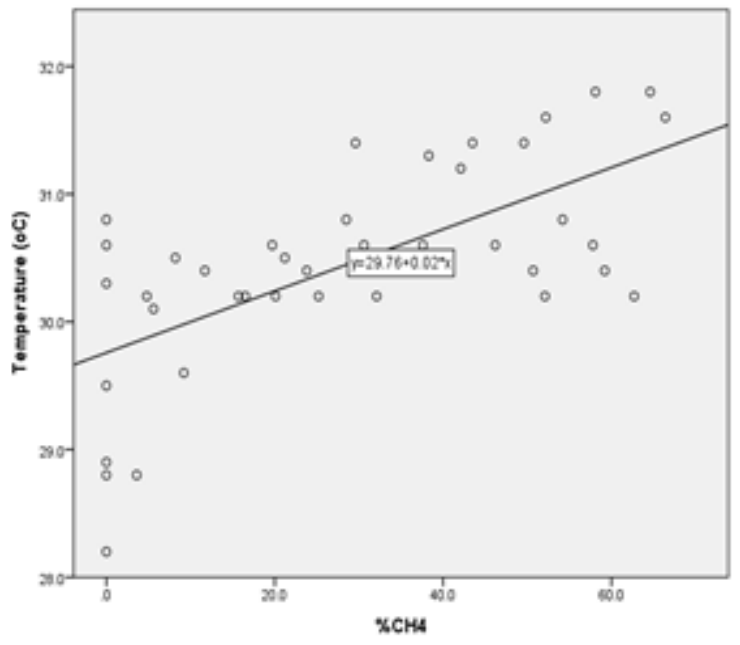

Fig 3: Association between biogas quality $\left(\% \mathrm{CH}_{4}\right)$ and Temperature for PM-aided WH digestion
The results corresponds to those recorded Ntengwe (2010) but are at variance with those recorded by Adegunloye et al. (2013). Dobre et al. (2014) affirmed that temperature within the digester is critical to the AD process, it has a strong influence on the quality of the produced biogas. The results also revealed that the PM-aided WH mix produced more gas but with less methane content compared to the CD-aided and PDaided WH digestion mix. The results further revealed that the best quality of gas was produced by the PDaided $\mathrm{WH}$ digestion.

Conclusion: The association between biogas quality and fermentation temperature for mix ratios of codigested WH with $\mathrm{PD}, \mathrm{CD}$ and $\mathrm{PM}$ on biogas production was evaluated. The data obtained were analyzed using non-linear parameter estimation. The association between the temperature and gas quality was positive suggesting that an increase in temperature within the digestion leads to an increase in the quality of gas produced. Decisively, the temperature within an anaerobic digester is important in anaerobic digestion and has a strong influence on the quality of the produced biogas.

\section{REFERENCES}

Abdel-Hadi, MA; Abd El-Azeem, SAM (2008). Effect of heating, mixing and digester type on biogas production from buffalo dung. Misr Journal of Agricultural Engineering. 25(4): 1454-1477.

Adegunloye, DV; Olosunde, SY; Omokanju, AB (2013). Evaluation of Ratio Variation of Water Hyacinth (Eichhornia Crassipes) on the Production of Pig Dung Biogas. International Research Journal of Biological Sciences. 2(3): 44 - 48.

Angelidaki, I; Sorensen, AH; Schmidt, JE (2007). Notes for the course 12133: "Environmental Biotechnology". Technical University of Denmark, Lyngby, Denmark

Deublein, D; Steinhauser, A (2008). Biogas from Waste and Renewable Resources: An introduction. Wiley-VCH, Weinheim, Germany.

Dobre, P; Nicolae, F; Matei, F (2014). Main factors affecting biogas production - An overview. Romanian Biotechnological Letters. 19 (3): 9283 - 9296.

El-Mashad, HM; Zeeman, G; Van Loon, WKP; Bot, GPA; Lettinga G (2004). Effect of temperature and temperature fluctuation on 
thermophilic anaerobic digestion of cattle manure. Bioresource Technology. 95: 191-201.

Erickson, LE; Fayet, E; Kakumanu, BK; Davis, LC (2005). Anaerobic Digestion. National Agricultural Biosecurity Center, Kansas State University, Kansas.

Fekadu, M (2014). Biogas production from Water Hyacinth (eichhornia crassipes) Co-digestion with cow-dung. M.Sc thesis, Department of Biology, Haramaya University

Gerardi, MH (2003). The Microbiology of Anaerobic Digesters. John Wiley \&Sons, Inc. Hoboken, New Jersey.

Knottier, M (2003). Integration of biogas technology, organic farming and energy crops. The future of biogas in Europe II, European biogas workshop. University of Southern Denmark.

Ntengwe, FW; Lawrence, N; George, K; Lordwel, KW (2010). Biogas Production in cone-closed floating dome batch digester under tropical conditions. International Journal of ChemTech Research. 2(1):483 - 492.

Ojo, OM (2017). Biomethanation of Water Hyacinth and Selected Animal Dungs for Biogas Production. Unpublished Ph.D Thesis in the Department of Civil Engineering, the Federal University of Technology, Akure.

Ojo, OM; Babatola, JO; Akinola, AO (2018). Regression Analysis of Biogas Production from the Co-Digestion of Water Hyacinth and Pig Dung. FUOYE Journal of Engineering and Technology. 3(2): 141 - 144
Parker, DB; Williams, DL; Cole, NA; Auvermann, BW; Rogers, WJ (2002). Dry heated Anaerobic Biogas Fermentation Using Aged Beef Cattle Manure, ASABE Meeting Paper No. 024142.

Poliafico, M (2007). Anaerobic Digestion: Decision support software. Master's Thesis, Department of Civil, Structural and Environmental Engineering, Cork Institute of Technology, Cork, Ireland.

Rastogi, G; Ranade, D; Yeole, TY; Patole, MS; Shouche, YS. (2007). Investigation of methanogen population structure in biogas reactor by molecular characterization of methylcoenzyme $M$ reductase A ( $\mathrm{mcr} A)$ genes. Bioresource Technology. 99: 5317 - 5326.

Shuler, ML and Kargi, F (2002). Bioprocess Engineering: Basic Concepts. Second Edition. Upper Saddle River, New Jersey. Prentice Hall Inc.

Tchobanoglous G; Burton FL; Stensel, HD (2003). Wastewater Engineering, Treatment and Reuse. Fourth edition. Metcalf \& Eddy, Inc., McGrawHill Science Engineering pp 629-632, 983-1026.

Wang, H; Lehtomaki, A; Tovanen, K; Puhakka, J (2009). Impact of crop species on bacteria community structure during anaerobic codigestion of crops and cow manure. Bioresource Technology. 100: 2311-2315

Ward AJ; Hobbs, J; Holliman, PJ (2008). Review: Optimization of the anaerobic digestion of agricultural resources. Bioresource Technology. 99: 7928-7940. 